\title{
Activity, Selectivity, and Stability of Vanadium Catalysts in Formaldehyde Production from Emissions of Volatile Organic Compounds
}

Tiina Laitinen $^{\mathrm{a}}$, Satu Ojala ${ }^{\mathrm{a}}$, Renaud Cousin ${ }^{\mathrm{b}}$, Niina Koivikko ${ }^{\mathrm{a}}$, Christophe Poupin ${ }^{\mathrm{b}}$, Zouhair El Assal ${ }^{\mathrm{a}}$, Atte $\mathrm{Aho}^{\mathrm{c}}$ and Riitta L. Keiski ${ }^{*}$

a Environmental and Chemical Engineering (ECE), Faculty of Technology, P.O. Box 4300, Fl-90014 University of Oulu, Finland

b Unité de Chimie Environnementale et Interactions sur le Vivant (UCEIV), Université du Littoral Côte d'Opale, 59140 Dunkerque, France

c Laboratory of Industrial Chemistry and Reaction Engineering, Johan Gadolin Process Chemistry Centre, Åbo Akademi University, Biskopsgatan 8, 20500 Åbo, Finland ${ }^{*}$ corresponding author: Environmental and Chemical Engineering (ECE), Faculty of Technology, P.O. Box 4300, Fl-90014 University of Oulu, Finland

E-mail addresses: tiina.laitinen@oulu.fi (T. Laitinen), satu.ojala@oulu.fi (S. Ojala), Renaud.Cousin@univ-littoral.fr (R.Cousin),niina.koivikko@oulu.fi (N.Koivikko), Christophe.Poupin@univ-littoral.fr (C.Poupin), zouhair.el.assal@oulu.fi (Z. El Assal), ataho@abo.fi (A. Aho),riitta.keiski@oulu.fi (R.L.Keiski) 


\section{Abstract}

In this study, activity, selectivity and stability of vanadium catalysts supported on zirconia, hafnia, and alumina were examined in the oxidation of methanethiol and methanol to formaldehyde. The $3 \mathrm{wt}-\%$ vanadia-alumina catalyst with low $\mathrm{VO}_{x}$ surface density showed the highest activity in the formaldehyde production. However, during the stability test, this catalyst deactivated due to the change in the oxidation state of vanadium from $\mathrm{V}^{5+}$ to $\mathrm{V}^{4+}$, decrease the amount of surface vanadium species and the formation of sulphates on the material surface. Zirconia and hafnia supported catalysts with high $\mathrm{VO}_{\mathrm{x}}$ surface density demonstrated better stability in the reaction conditions, but their activity in the formaldehyde production was lower. One reason for the lower activity might be the formation of metal-mixed oxide phases between vanadia and the support, which could also explain the decreased sulphur deposition on zirconia and hafnia after vanadium impregnation.

Keywords: environmental catalysis, oxidation, sulfur poisoning, supported catalysts, VOC emission utilization

\section{Introduction}

Volatile organic compounds (VOCs) are emitted from various industrial sources causing harmful effects on the environment, atmosphere and human health. One interesting route to reduce the industrial emissions is to utilize emissions in the production of valuable chemicals. Utilization of emissions is an important research field both from the economic and sustainable development point of views. VOC emissions consist of hundreds of different compounds, thus there exist many potential ways to use VOCs in the production 
of valuable chemicals [1]. Still, only a few studies present utilization possibilities for gaseous organic emissions.

Significant amounts of methanol $(\mathrm{MeOH})$ emissions are formed in the Kraft pulp mills. Methanol is formed during the pulping of wood and it is collected from the black liquor evaporation plant. The amount of methanol produced during the pulping process is about $6-20 \mathrm{~kg}$ per ton of pulp and the concentration of the formed methanol is $40-80 \%$ depending on the treatment process of the emission streams [2-5]. This methanol is contaminated with reduced sulphur compounds (TRS), and therefore it is typically incinerated.

In this research, utilization of contaminated methanol in formaldehyde production is considered. Methanethiol (MT) is used as the representative compound of TRS.

Formaldehyde is a valuable chemical in the chemical industry and its production from contaminated methanol could be economically more interesting for the pulp mills than use of contaminated methanol as an energy source.

The reactions to produce formaldehyde from methanol and methanethiol are partial oxidation reactions, or more accurately, oxidative dehydrogenation of methanol (Reaction 1) and oxidative desulphurization of methanethiol (Reaction 2).

$\mathrm{CH}_{3} \mathrm{OH}+1 / 2 \mathrm{O}_{2} \rightarrow \mathrm{HCHO}+\mathrm{H}_{2} \mathrm{O}$

$\mathrm{CH}_{3} \mathrm{SH}+2 \mathrm{O}_{2} \rightarrow \mathrm{HCHO}+\mathrm{SO}_{2}+\mathrm{H}_{2} \mathrm{O}$

Supported vanadium oxide catalysts are selective and active materials in the partial oxidation of hydrocarbons, including methanol oxidation to formaldehyde, which is why vanadium oxide has been selected as an active phase for the current study. Depending on 
the support and $\mathrm{VO}_{\mathrm{x}}$ surface density, supported vanadium oxide can exist as isolated monovanadate species, two-dimensional polyvanadate species, or bulk $\mathrm{V}_{2} \mathrm{O}_{5}$ crystallites [6-9]. In general, acidic $\mathrm{V}_{2} \mathrm{O}_{5}$ species interact weakly with acidic supports (e.g. $\mathrm{SiO}_{2}$ ), leading to $\mathrm{V}_{2} \mathrm{O}_{5}$ crystallites at lower $\mathrm{VO}_{x}$ surface density [10]. The structure and distribution of the vanadia species are affecting activity, selectivity, and stability of supported vanadia catalysts [11-13]. According to the current knowledge, activity of the supported vanadium oxide catalysts depends on the presence of surface monovanadate and polyvanadate species. The surface crystalline $\mathrm{V}_{2} \mathrm{O}_{5}$ above monolayer coverage tends to be less active in the oxidation reactions. $[13,14]$ On the other hand, when gas composition consists of methanethiol, stability of materials in the presence of sulphur is a very important factor. According to Soriano et al. [11,12] and Wang et al. [15], $\mathrm{V}_{2} \mathrm{O}_{5}$ crystallite and metal-mixed oxide phases may decrease deposition of sulphur on the catalysts surface, which enhances the stability of the catalysts.

Many support oxides (e.g. $\mathrm{Al}_{2} \mathrm{O}_{3}, \mathrm{ZrO}_{2}, \mathrm{TiO}_{2}$, and $\mathrm{SiO}_{2}$ ) have been investigated in the methanol oxidative dehydrogenation to formaldehyde, but methanethiol and especially partial oxidation of a mixture of methanol and methanethiol has been less investigated. For the current study, we selected $\gamma-\mathrm{Al}_{2} \mathrm{O}_{3}, \mathrm{HfO}_{2}$ and $\mathrm{ZrO}_{2}$ as the support materials. These selected supports allow good dispersion of surface vanadium oxide species $[9,13,16]$, which improves the activity of catalysts in the oxidation of mixture of methanol and methanethiol [17]. Alumina was selected, even though the sulphur resistance of pure alumina is not very good, since alumina supported vanadia catalysts are known to be highly active in methanol to formaldehyde reaction $[18,19]$. Hafnium is chemically very similar to zirconium [20], but less studied as a support of catalysts. Zirconia and hafnia are interesting materials, because at high calcination temperatures, it is possible to form metal 
vanadate species on the highly loaded $\mathrm{VO}_{x} / \mathrm{ZrO}_{2}$ and $\mathrm{VO}_{x} / \mathrm{HfO}_{2} .[6,16,21]$ These kind of mixed metaloxide phases may improve resistance to deactivation of catalysts by sulphur compounds. $[11,12,15]$

To summarize, this study focuses on the activity, selectivity, and stability of supported vanadium oxide catalysts in the partial oxidation of a mixture of methanol and methanethiol to produce formaldehyde. Three support materials $\left(\mathrm{ZrO}_{2}, \mathrm{HfO}_{2}\right.$ and $\left.\gamma-\mathrm{Al}_{2} \mathrm{O}_{3}\right)$ are examined with and without $3 w t-\%$ of vanadium impregnation to discover the catalytic performance of these materials in the described reactions. The physico-chemical properties of the catalysts are studied using $\mathrm{N}_{2}$ physisorption, X-ray fluorescence (XRF) spectroscopy, temperature programmed desorption of ammonia ( $\left.\mathrm{NH}_{3}-\mathrm{TPD}\right)$ and pyridine, $\mathrm{X}$-ray powder diffraction (XRD), scanning transmission electron microscopy (STEM), X-ray photoelectron spectroscopy (XPS), the electron paramagnetic resonance (EPR) measurements and novel time-gated Raman spectroscopy, and relations between performance and the characteristics are drawn.

\section{Materials and methods}

\section{Catalyst preparation}

The vanadium catalysts, $3 \mathrm{wt}-\% \mathrm{~V}_{2} \mathrm{O}_{5} / \mathrm{ZrO}_{2}(\mathrm{VZr}), 3 \mathrm{wt}-\% \mathrm{~V}_{2} \mathrm{O}_{5} / \mathrm{HfO}_{2}(\mathrm{VHf})$ and $3 \mathrm{wt}-\%$ $\mathrm{V}_{2} \mathrm{O}_{5} / \gamma-\mathrm{Al}_{2} \mathrm{O}_{3}(\mathrm{VAl})$, were prepared by a wet impregnation method. Before impregnation, commercial $\mathrm{ZrO}_{2}\left(99 \%, 5 \mu \mathrm{m}\right.$, Sigma-Aldrich) and $\gamma-\mathrm{Al}_{2} \mathrm{O}_{3}(99.97 \%, 63 \mu \mathrm{m}$, Merck) supports were calcined at $600^{\circ} \mathrm{C}$ and $\mathrm{HfO}_{2}(99 \%,-325$ mesh $\sim<44 \mu \mathrm{m}$, Alfa Aesar) at $800^{\circ} \mathrm{C}$ for 4 hours. After calcination, the supports were impregnated with vanadyl acetylacetonate $\mathrm{VO}(\mathrm{acac}) 2$ (98\% Sigma-Aldrich) dissolved in methanol (99.9\% Merck) at room temperature for 20 hours. After impregnation, the catalysts were dried on a sand 
bath at $90^{\circ} \mathrm{C}$ for 5 hours and then kept in a heated oven at $120^{\circ} \mathrm{C}$ for 2 hours. Finally, all catalysts were calcined at $600^{\circ} \mathrm{C}$ for 4 hours. Calcination temperature was selected based on the thermogravimetric analysis (TGA) and temperature used in the experiments (see the supplementary material).

\section{Catalyst characterisation}

Nitrogen physisorption at $-196^{\circ} \mathrm{C}$ using a Micromeritics ASAP2020 analyzer was used to determine specific surface areas of the materials with the Brunauer-Emmet-Teller (BET) method. The pore sizes and total pore volume distributions were determined by the Barrett-Joyner-Halenda (BJH) method. Prior to the analysis, the samples were evacuated first at $150^{\circ} \mathrm{C}$ for $30 \mathrm{~min}$ and then at $300^{\circ} \mathrm{C}$ for $120 \mathrm{~min}$ to clean the surface of the sample.

The chemical compositions of the catalysts were determined by using a PANalytical ${ }^{\circledR}$ AXIOS mAX 4kW X-ray fluorescence (XRF) spectrometer and the Omnian standardless analysis method. The fused bead samples were prepared using an Eagon2 furnace. Before fusion, the sample $(500 \mathrm{mg})$ was mixed with fusion chemicals $(8.5 \mathrm{~g}$ Lithium tetraborate 66\%:Lithium metaborate 34\%) and loaded into a crucible. During fusion, $\mathrm{NH}_{4} \mathrm{I}$ $(16 \mathrm{mg})$ was added as a releasing agent into the melt before casting it on a $38 \mathrm{~mm}$ casting dish.

Total acidities of the fresh samples were determined by temperature programmed desorption of ammonia ( $\mathrm{NH}_{3}$-TPD). $\mathrm{NH}_{3}$-TPD was performed on an AutoChem II 2920 equipment. The amount of $55 \mathrm{mg}$ of a sample was pre-treated in a He flow $\left(50 \mathrm{~cm}^{3} \mathrm{~min}^{-1}\right)$ for $30 \mathrm{~min}$ at $500^{\circ} \mathrm{C}$ and cooled down to room temperature $\left(25^{\circ} \mathrm{C}\right)$ under a $\mathrm{He}$ flow. $\mathrm{NH}_{3}$ adsorption (15\% $\mathrm{NH}_{3}$ in $\mathrm{He}, 50 \mathrm{~cm}^{3} \mathrm{~min}^{-1}$ ) was done at room temperature during $60 \mathrm{~min}$.

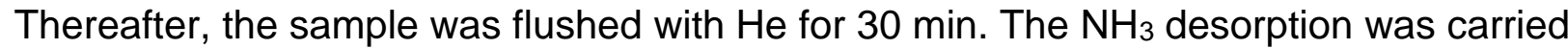


out under a He flow from room temperature to $500^{\circ} \mathrm{C}\left(5^{\circ} \mathrm{C} \mathrm{min}{ }^{-1}\right)$ with the He flow rate of $50 \mathrm{~cm}^{3} \mathrm{~min}^{-1}$. The desorbed concentration of $\mathrm{NH}_{3}$ was analysed by a TCD detector. The total acidity of samples was determined by integration of the area between $40-500^{\circ} \mathrm{C}$.

The quality of the acid sites was determined with pyridine adsorption. The Brønsted and Lewis acidity of the catalysts was measured by infrared spectroscopy (ATI Mattson FTIR) using pyridine as a probe molecule. A thin (30-100 mg) self-supported wafer of the catalyst was pressed and then placed into the FTIR-cell. The cell was evacuated and checked for possible leakages. The catalyst wafer was pre-treated in a $10 \mathrm{~cm}^{3} \mathrm{~min}^{-1}$ flow of synthetic air at $450^{\circ} \mathrm{C}$ for $1 \mathrm{~h}$. Thereafter, the temperature was decreased to $100^{\circ} \mathrm{C}$ and the cell evacuated for 15 min prior to recording of the background spectra. Pyridine was adsorbed on the sample for $30 \mathrm{~min}$ at $100^{\circ} \mathrm{C}$ followed by desorption at 250,350 and $450^{\circ} \mathrm{C}$ for $1 \mathrm{~h}$ and the spectra of the sample were recorded between every temperature ramp. The scanning was performed under vacuum at $100^{\circ} \mathrm{C}$. Spectral bands at $1545 \mathrm{~cm}^{-1}$ and at $1450 \mathrm{~cm}^{-1}$ were used to identify Brønsted and Lewis acid sites, respectively. The quantitative amount of the acid sites was calculated with the constants of Emeis [22].

The catalysts' crystalline phases and sizes were identified at room temperature by X-ray powder diffraction (XRD). As an apparatus, D8 Advance diffractometer, (Bruker AXS) LynxEye Detector with a copper radiation source was used. The XRD spectra for fresh and used $\gamma-\mathrm{Al}_{2} \mathrm{O}_{3}$ were collected using the step-size of $0.02^{\circ}$ and $2 \theta$ (Bragg angle) range from 10 to 90 with a count time of $2 \mathrm{~s}$ per step. For all the other samples, the scattering intensities were measured over an angular range of $15^{\circ} \leq 2 \theta \leq 35^{\circ}$. The diffraction patterns were indexed by comparison with the "Joint Committee on Powder Diffraction Standards" (JCPDS) files. Crystallite sizes $\left(d_{c r}\right)$ were determined using the Scherrer equation: 
$d_{c r}=\frac{k \lambda}{\beta \cos \theta}$

where $\mathrm{k}$ is the crystallite shape factor $(k=0.9), \lambda$ is the X-ray wavelength $(\lambda=0.15406 \mathrm{~nm}$ for Cu radiation source), $\theta$ is the Bragg angle, and $\beta$ is the corrected line broadening defined as FWHM (full width at half maximum).

A Scanning transmission electron microscope (STEM) was used in the visualization of the surface of the catalysts. Prior to the microscopy, the catalysts were dispersed in ethanol by ultrasound. A small amount of the mixture of ethanol and catalysts was deposited on a coaled copper grid. Measurements were performed with a JEOL JEM-2200FS equipment that uses acceleration voltage of $80-200 \mathrm{kV}$. An energy dispersive X-ray spectroscopy (EDS, JEOL Dry SD100GV) was used in the identification of the elements.

Raman spectroscopy was used to identify the vanadia species present on the catalysts surface. With the novel timegated Raman (TG-Raman) spectroscopy it is also possible to minimize the effect of fluorescence in the measurements [23], in which case more exact spectral information can be obtained compared with a conventional Raman device. The Raman spectra were collected with a Timegated® 532 Raman Spectrometer (Model M1) that uses a fibre coupled pulsed $532 \mathrm{~nm}$ laser and a single photon counting CMOS SPAD matrix detector with 100 ps time resolution. The system allows suppression of the possible fluorescence interference. The data were collected with the Raman shift range from 100 to $1100 \mathrm{~cm}^{-1}$ and 1000 to $1700 \mathrm{~cm}^{-1}$ with the spectral resolution of $10 \mathrm{~cm}^{-1}$. In the data treatment, wavelets and the $2^{\text {nd }}$ derivate were used to reduce the background.

The electron paramagnetic resonance (EPR) measurements were performed at room temperature and $-196^{\circ} \mathrm{C}$ on an EMX BRUKER spectrometer with a cavity operating at a frequency of $\sim 9.5 \mathrm{GHz}$ ( $\mathrm{X}$ band). The magnetic field was modulated at $100 \mathrm{kHz}$, and the 
power supply was sufficiently low to avoid saturation effects. EPR measurements were done to determine possible presence of vanadium (IV) on the catalysts.

The X-ray photoelectron spectroscopy (XPS) was used to find out information on the oxidation states of vanadium, but also to evaluate the sulphur deactivation of the materials. XPS analysis was performed with a Thermo Fisher Scientific ESCALab 250Xi spectrometer with an $\mathrm{Al} \mathrm{K \alpha}(1486.6 \mathrm{eV})$ radiation source and pass energy of $20 \mathrm{eV}$. The samples were placed on the sample disk on the indium substrate. The data was analysed by the ThermoAvantage -software program and the signals were fitted with the mixed Gaussian-Lorentzian function. Binding energies were referred to the $\mathrm{C} 1 \mathrm{~s}$ peak line at $284.8 \mathrm{eV}$ and Smart function was used to reduce the background.

\section{Light-off and stability tests}

Catalytic tests (light-off tests) for partial oxidation of mixture of methanol $(\mathrm{MeOH})$ and methanethiol (MT) were carried out with a laboratory scale equipment, which has been described in more detail in Koivikko et al. [5]. The air flow $\left(0.75 \mathrm{dm}^{3} \mathrm{~min}^{-1}\right)$ and the MT flow $\left(0.25 \mathrm{dm}^{3} \mathrm{~min}^{-1}\right)$ were controlled with mass flow controllers (MFCs). Liquid MeOH was fed with a syringe pump to the vaporizer before mixing with air. The total gas flow $\left(1 \mathrm{dm}^{3} \mathrm{~min}^{-1}\right)$ contained $500 \mathrm{ppm} \mathrm{MT}$ and $500 \mathrm{ppm} \mathrm{MeOH}$ in air. The composition of the gas mixture was followed by an FTIR analyser (Gasmet $\left.{ }^{\mathrm{TM}} \mathrm{CR}-2000\right)$. The measured compounds were: water vapour $\left(\mathrm{H}_{2} \mathrm{O}\right)$, carbon dioxide $\left(\mathrm{CO}_{2}\right)$, carbon monoxide $(\mathrm{CO})$, nitrogen monoxide (NO), nitrogen dioxide $\left(\mathrm{NO}_{2}\right)$, nitrous oxide $\left(\mathrm{N}_{2} \mathrm{O}\right)$, sulphur dioxide $\left(\mathrm{SO}_{2}\right)$, methane $\left(\mathrm{CH}_{4}\right)$, sulphur trioxide $\left(\mathrm{SO}_{3}\right)$, formaldehyde $(\mathrm{CHOH})$, methanethiol $\left(\mathrm{CH}_{3} \mathrm{SH}\right)$, dimethyl sulphide ( $\left.\mathrm{C}_{2} \mathrm{H}_{6} \mathrm{~S}\right)$, dimethyl disulphide $\left(\mathrm{C}_{2} \mathrm{H}_{6} \mathrm{~S}_{2}\right)$, formic acid $\left(\mathrm{CH}_{2} \mathrm{O}_{2}\right)$, and methanol $\left(\mathrm{CH}_{3} \mathrm{OH}\right)$. 
First, the activities of the materials were evaluated with the light-off tests carried out from $100^{\circ} \mathrm{C}$ up to $600^{\circ} \mathrm{C}$ with the heating rate of $5^{\circ} \mathrm{Cmin}^{-1}$. The catalyst $(100 \mathrm{mg})$ was loaded in the quartz reactor between quartz sand (QS, total $900 \mathrm{mg}$ ) and quartz wool.

The same reactor set-up was used in the stability tests. The catalyst $(300 \mathrm{mg})$ was packed in the reactor between quartz wool plugs without using quartz sand. At the beginning of the stability experiment, one light-off test was done with the heating rate of $5^{\circ} \mathrm{Cmin}^{-1}$ starting from $100^{\circ} \mathrm{C}$ up to the selected temperature, which was dependent on the catalyst used. The temperature for the stability test was selected based on the light-off tests carried out earlier representing the temperature where nearly $100 \%$ conversion of MT and 70-100\% conversion of methanol was achieved. These temperatures are shown in Table 1. The materials were kept at the selected constant temperature for 16 hours. The 16 hours run was done during three consecutive days. At the end of the stability experiment, a second light-off test was performed by using the same procedure than earlier.

Table 1. Selected temperatures for the stability tests.

\begin{tabular}{ll}
\hline Catalyst & $\mathrm{T}\left[{ }^{\circ} \mathrm{C}\right]$ \\
\hline $\mathrm{ZrO}_{2}$ & 490 \\
$\mathrm{HfO}_{2}$ & 490 \\
$\gamma-\mathrm{Al}_{2} \mathrm{O}_{3}$ & 510 \\
$\mathrm{VZr}$ & 425 \\
$\mathrm{VHf}$ & 450 \\
VAl & 355 \\
\hline
\end{tabular}


The conversion of $\mathrm{MeOH}\left(X_{\mathrm{MeOH}}\right)$ and $\mathrm{MT}\left(X_{M T}\right)$ as well as formaldehyde yield $\left(Y_{F O}\right)$ and selectivity $\left(S_{F O}\right)$ were calculated as follows:

$X_{\mathrm{MeOH}}=\frac{C_{\mathrm{MeOH}, \text { in }}-C_{\mathrm{MeOH}, \mathrm{out}}}{C_{\mathrm{MeOH}, \text { in }}} * 100 \%$

$X_{M T}=\frac{C_{M T, \text { in }}-C_{M T, \text { out }}}{C_{M T, \text { in }}} * 100 \%$

$Y_{F O}=\frac{C_{F O}}{C_{M e O H, \text { in }}+C_{M T, \text { in }}} * 100 \%$

$S_{F O}=\frac{C_{F O}}{C_{\text {products, out }}} * 100 \%$

where $\mathrm{CMeOH}_{\mathrm{H}}$, and $\mathrm{CMT}_{\mathrm{T}}$, in are reactants inlet concentration and $\mathrm{CMeOH}_{\text {, out }}$ and $\mathrm{C}_{M T}$, out are reactants outlet concentration. Furthermore, $C_{F O}$ is the outlet concentration of

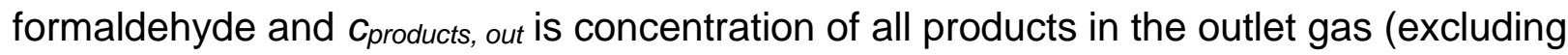
water).

\section{Results and discussion}

\subsection{Oxidation of methanol and methanethiol mixture}

Figures 1.a-b show the formaldehyde (FO) production from the mixture of methanol $(\mathrm{MeOH})$ and methanethiol (MT) during the light-off tests. Of the supports, $\mathrm{ZrO}_{2}$ and $\mathrm{HfO}_{2}$ showed higher activity than $\gamma-\mathrm{Al}_{2} \mathrm{O}_{3}$ in formaldehyde production. Interestingly, after impregnation of vanadium, the $\gamma-\mathrm{Al}_{2} \mathrm{O}_{3}$-supported catalyst was significantly more active than the $\mathrm{ZrO}_{2}$ and $\mathrm{HfO}_{2}$ supported ones (see Fig 1.b). Figure 1.c indicates, that the MT conversion is nearly complete over all the supports and catalysts, and also without a catalyst. It is noteworthy that methanethiol reacts at almost the same temperature with $\mathrm{ZrO}_{2}$ and $\mathrm{HfO}_{2}$ supports and without a catalyst signifying minor effect of supports on MT 
reaction. Figure 1d shows, that methanol reacts at considerably higher temperature than methanethiol (see Fig 1.d). The results reveal also, that methanethiol and methanol are converted at lower temperature over the alumina samples compared to zirconia and hafnia samples.

Figure 1. a) Formaldehyde concentration vs. temperature for supports, quartz sand (QS), and the test without a catalyst (empty reactor) (No Cat); b) Formaldehyde concentration vs. temperature for the impregnated catalysts; c) MT concentration vs. temperature; d) $\mathrm{MeOH}$ concentration vs. temperature.

Methanethiol and methanol conversions and the formaldehyde selectivity and yield were calculated at optimal formaldehyde production temperature for all the cases (Table 2). Based on the reaction Equations 1 and 2 the maximum theoretical selectivity of formaldehyde is $67 \%$ when water formation is ignored. From the Table 2 , it can be noted, that impregnation of vanadia on the supports increases methanol conversion, formaldehyde yield and selectivity. The best result was obtained with the VAl catalyst, in which case the yield of formaldehyde was $99 \%$ already at $400^{\circ} \mathrm{C}$. The differences in selectivities of $\mathrm{VZr}$, VHf and VAl at optimal formaldehyde production temperature are minor. It is also noteworthy that without a catalyst and with the $\gamma-\mathrm{Al}_{2} \mathrm{O}_{3}$ support, the obtained formaldehyde selectivity and yield were very low. 
Table 2. Methanethiol and methanol conversions, formaldehyde selectivity and yield at optimal temperatures.

\begin{tabular}{lccccc}
\hline Catalyst & Optimal T [ $\left.{ }^{\circ} \mathrm{C}\right]$ & $\mathrm{X}_{\mathrm{MT}}[\%]$ & $\mathrm{X}_{\mathrm{MeOH}}[\%]$ & $\mathrm{S}_{\mathrm{FO}}[\%]$ & $\mathrm{Y}_{\mathrm{FO}}[\%]$ \\
\hline No catalyst & 550 & 100 & 0 & 22 & 34 \\
$\mathrm{QS}^{\mathrm{a}}$ & 590 & 100 & 32 & 31 & 47 \\
$\mathrm{ZrO}_{2}$ & 530 & 100 & 64 & 39 & 64 \\
$\mathrm{HfO}_{2}$ & 510 & 100 & 50 & 38 & 59 \\
$\gamma-\mathrm{Al}_{2} \mathrm{O}_{3}$ & 550 & 99 & 95 & 25 & 35 \\
$\mathrm{VZr}$ & 500 & 96 & 96 & 60 & 90 \\
$\mathrm{VHf}$ & 485 & 93 & 86 & 58 & 90 \\
$\mathrm{VAl}$ & 400 & 100 & 93 & 59 & 99 \\
\hline
\end{tabular}

aQS: Quartz sand

The main by-products observed during the reaction over the support oxides and with empty reactor (see supplementary material Fig S2) were dimethyl disulphide (DMDS), carbon monoxide (CO), and dimethyl sulphide (DMS). The concentrations of the other detected compounds were very small. The DMDS formation was similar in non-catalytic tests and in the experiments with the support oxides. Thus, it seems that in these cases DMDS is formed via a non-catalytic reaction. DMDS can be formed from MT according to Equation 8 at temperatures of about $\sim 300^{\circ} \mathrm{C}[24,25]$ :

$2 \mathrm{CH}_{3} \mathrm{SH}+1 / 2 \mathrm{O}_{2} \rightarrow\left(\mathrm{CH}_{3}\right)_{2} \mathrm{~S}_{2}+\mathrm{H}_{2} \mathrm{O}$

Over $\gamma-\mathrm{Al}_{2} \mathrm{O}_{3}$, the final conversions of methanethiol and methanol in the mixture were considerably higher than over $\mathrm{ZrO}_{2}$ and $\mathrm{HfO}_{2}$. However, the selectivity to formaldehyde over $\gamma-\mathrm{Al}_{2} \mathrm{O}_{3}$ remained low, because more by-products (DMS and $\mathrm{CO}$ ) were formed compared to the cases where the other two supports were used. It has been observed that 
$\mathrm{CH}_{3} \mathrm{SH}$ can be converted into DMS and hydrogen sulphide $\left(\mathrm{H}_{2} \mathrm{~S}\right)$ at $300^{\circ} \mathrm{C}$ over the zeolite catalysts according to Equation 9 [26-28]:

$2 \mathrm{CH}_{3} \mathrm{SH} \rightarrow \mathrm{CH}_{3} \mathrm{SCH}_{3}+\mathrm{H}_{2} \mathrm{~S}$

According to Reuss et al. [29], $\mathrm{CO}$ can be formed at high temperatures $\left(>470^{\circ} \mathrm{C}\right.$, metal oxide catalysts) from the produced formaldehyde via the side reaction:

$\mathrm{CH}_{2} \mathrm{O}+1 / 2 \mathrm{O}_{2} \rightarrow \mathrm{CO}+\mathrm{H}_{2} \mathrm{O}$

The addition of vanadia on alumina decreased markedly the formation of DMS as the byproduct. With the VAl catalyst the amount of carbon monoxide rises rapidly when the temperature increases over the optimum formaldehyde production temperature $\left(T>400^{\circ} \mathrm{C}\right)$. This indicates incomplete oxidation of formaldehyde according to Equation (10).

In the light-off tests, a significant amount of $\mathrm{SO}_{2}$ was also formed, as expected (see Reaction 2). Concentrations of $\mathrm{SO}_{2}$ vs. reaction temperature for vanadium catalysts, $\mathrm{ZrO}_{2}$ and without a catalyst are presented in Figure 2. With the $\mathrm{HfO}_{2}$ and $\gamma-\mathrm{Al}_{2} \mathrm{O}_{3}$ supports, similar results were obtained than with $\mathrm{ZrO}_{2}$ and thus, they are not included in the figure. The concentration of $\mathrm{SO}_{2}$ stabilized at the lowest temperature $\left(470^{\circ} \mathrm{C}\right)$ over the VAI catalyst. With other catalysts and supports, the maximum $\mathrm{SO}_{2}$ formation was achieved at $540-550^{\circ} \mathrm{C}$. Without a catalyst, stable $\mathrm{SO}_{2}$ formation was achieved at higher temperature $\left(>600^{\circ} \mathrm{C}\right)$. Formation of $\mathrm{SO}_{2}$ followed the same order than the MT conversion over the other samples, except alumina (see Fig 1.c). Besides formaldehyde and water, $\mathrm{SO}_{2}$ is the main product of the MT reaction. It is a harmful emission compound, that is routinely treated in modern pulp mills. Thus, after separation of formaldehyde product, $\mathrm{SO}_{2}$ together with other possible impurities needs to be conducted to the further treatment. From the 
catalyst stability point of view, formation of $\mathrm{SO}_{2}$ is beneficial, since if sulphur is not removed in the product stream, the deactivation of the catalyst is difficult to be avoided.

Figure 2. $\mathrm{SO}_{2}$ concentration vs. temperature for impregnated catalysts, $\mathrm{ZrO}_{2}$ and the test without a catalyst (No Cat).

\subsection{Stability tests}

The results of the $16 \mathrm{~h}$ stability tests are presented in the supplementary material. During the stability tests, the MT conversion was nearly $100 \%$ with all the tested materials. Methanol conversion was nearly $100 \%$ over $\mathrm{VAl}$, VHf, and $\gamma-\mathrm{Al}_{2} \mathrm{O}_{3}$. Over $\mathrm{VZr}, \mathrm{ZrO}$, and $\mathrm{HfO}_{2}$, conversion of methanol was $75 \%, 75 \%$ and $70 \%$, respectively. The concentration of products (FO and $\left.\mathrm{SO}_{2}\right)$ and by-products $\left(\mathrm{CO}, \mathrm{CO}_{2}, \mathrm{DMS}\right.$, and DMDS) remained stable throughout the experiment with $\mathrm{ZrO}_{2}, \mathrm{HfO}_{2}$, VHf, and VAI. With the $\mathrm{VZr}$ catalyst, $\mathrm{MeOH}$ conversion decreased, which was also observed as a decrease in the formaldehyde production. At the same time, changes in the production of sulphur compounds were noticed; the concentration of $\mathrm{SO}_{2}$ decreased and the concentration of DMDS increased. With the $\gamma-\mathrm{Al}_{2} \mathrm{O}_{3}$ support MT conversion remained stable throughout the stability test, but $\mathrm{SO}_{2}$ concentration slightly decreased leading to an increased DMS concentration. Despite of high conversions of reactants over $\gamma-\mathrm{Al}_{2} \mathrm{O}_{3}$, it showed to be less selective, since more by-products were formed in expense of formaldehyde production.

Formaldehyde production before (fresh samples) and after (used samples) the stability test are presented in Figure 3. Before the first and the second light-off tests, the concentrations of $\mathrm{MT}$ and $\mathrm{MeOH}$ were verified via the by-pass line. There were no significant differences between the reactant amounts and for that reason the concentrations of the products can be compared reliably. However, it should be noted that during the stability tests, the 
sulphur balance remained incomplete, which indicates that a part of sulphur was retained by the catalyst or the equipment. As shown in Figure 3, all the tested support materials (ac) have kept their activity during the stability test and there are no significant differences in the light-off curves between the fresh and used supports. When comparing the light-off curves of the fresh and used catalysts (d-f), it can be observed that the change in the lightoff temperature is smallest with the hafnia-supported catalyst. On the other hand, the maximum concentration of formaldehyde was reached at much lower temperature with the alumina-supported catalyst that is not equally stable with the hafnia-supported catalyst.

Figure 3. Formaldehyde production vs. temperature over fresh and used a) $\mathrm{ZrO}_{2}$, b) $\mathrm{HfO}_{2}$, c) $\gamma-\mathrm{Al}_{2} \mathrm{O}_{3}$ d) $\left.\left.\mathrm{VZr}, \mathrm{e}\right) \mathrm{VHf}, \mathrm{f}\right) \mathrm{VAl}$.

$\mathrm{SO}_{2}$ and DMDS as well as methanethiol and methanol concentrations during the light-off tests for the fresh and the used catalysts are presented in supplementary material (Fig S4). No significant differences in MT reaction temperature before and after the stability tests over the studied catalysts were observed. Instead, the methanol reaction was shifted to a higher temperature level with all the used catalysts after the stability test. This may indicate slight deactivation of the catalysts. In this case, hafnia and alumina catalysts demonstrated a smaller activity change compared to zirconia. The formation of $\mathrm{SO}_{2}$ over the VZr catalyst was slightly affected at the medium temperature range. No significant differences in $\mathrm{SO}_{2}$ production were observed with $\mathrm{VHf}$ and VAI.

Some changes can be noticed in the formation of DMDS after the stability test with all the tested catalysts. In the case of VZr, a significant difference in the formation of DMDS between the fresh and used catalysts can be observed. During the stability test, the DMDS concentration increased up to $50 \mathrm{ppm}$. After the stability test, before the second light-off 
test, the catalyst and the reactor were flushed with air until the measured gas concentrations were close to zero. Then the flow through the reactor was closed and the oven was cooled down. It seems that VZr adsorbs DMDS that is released during the following experimental procedures. The similar behaviour was not observed with $\mathrm{VHf}$ and VAI. With the used VHf catalyst, the formation of DMDS decreased whereas with the VAI catalyst it increased. There are no significant changes in the formation temperature of DMDS with VHf and VAl. The increase in the DMDS formation indicates the changes in the selectivity of the catalyst towards the reaction (8). This change is most prominent with the zirconia and alumina supported catalysts.

\subsection{Characterisation}

The amount of $\mathrm{V}_{2} \mathrm{O}_{5}$, specific surface area, pore volume, pore size, and $\mathrm{VO}_{x}$ surface density of each sample are presented in Table 3. The XRF analysis showed that the intended vanadia content ( $3 \mathrm{wt}-\%$ ) of catalysts was obtained during the preparation quite well. The elemental analysis of the supports showed the presence of certain impurities. Commercial $\mathrm{ZrO}_{2}$ contained 1.8 wt- $\% \mathrm{HfO}_{2}, \mathrm{Al}_{2} \mathrm{O}_{3} 0.6$ wt- $\% \mathrm{Na}_{2} \mathrm{O}$ and $\mathrm{HfO}_{2} 0.6$ wt- $\% \mathrm{ZrO}_{2}$ as impurities. These impurities are typically observed with these oxides $[20,30,31]$. Based on the $\mathrm{N}_{2}$ physisorpion analysis, the $\gamma-\mathrm{Al}_{2} \mathrm{O}_{3}$ support and the $\gamma-\mathrm{Al}_{2} \mathrm{O}_{3}$ supported catalyst had significantly higher specific surface areas and total pore volumes than the $\mathrm{ZrO}_{2}$ and $\mathrm{HfO}_{2}$ supports and catalysts. Compared to the bare oxides, the catalysts show a slight reduction in the specific surface area after the vanadia impregnation, but there are no significant changes in the pore sizes and volumes. Due to higher surface area of alumina, the dispersion of vanadia is better on the alumina surface. According to Deo and Wachs [32], Wachs [7], and Khodakov et al. [10], vanadia exists as highly dispersed species at surface density below $\sim 7 \mathrm{VO}_{x}$ per $\mathrm{nm}^{2}$ on zirconia, hafnia, and alumina. Therefore, the 
alumina support with a high surface area can disperse up to $100 \%$ of vanadium oxide as the surface $\mathrm{VO}_{x}$ species whereas low surface area supports $\left(\mathrm{ZrO}_{2}\right.$ and $\left.\mathrm{HfO}_{2}\right)$ can only disperse about $0.4-0.5$ wt-\% of vanadium oxide. In the activity test the alumina support alone showed poor activity in the formaldehyde production (Fig 1), but after vanadium impregnation the alumina supported catalyst was significantly more active than the other catalysts. The high activity of the VAI catalyst is most probably related to the better dispersion of vanadium oxide on alumina that is responsible for the high number of active sites, while for $\mathrm{VZr}$ and $\mathrm{VHf}$, the number of the dispersed vanadium oxide active sites is much lower. Furthermore, depending on the $\mathrm{VO}_{\mathrm{x}}$ surface density, the vanadia species are different. This will be discussed later in this paper.

Table 3. $\mathrm{V}_{2} \mathrm{O}_{5}$ concentration, specific surface area, total pore volume and average pore size, $\mathrm{VO}_{\mathrm{x}}$ surface density, and the total acidity for supports and vanadium-containing catalysts.

\begin{tabular}{|c|c|c|c|c|c|c|}
\hline Catalyst & $\begin{array}{c}\mathrm{V}_{2} \mathrm{O}_{5} \\
\text { concentration } \\
{[\mathrm{wt}-\%]}\end{array}$ & $\begin{array}{l}\text { Specific } \\
\text { surface } \\
\text { area }\left[\mathrm{m}^{2} \mathrm{~g}^{-1}\right]\end{array}$ & $\begin{array}{c}\text { Total pore } \\
\text { volume } \\
{\left[\mathrm{cm}^{3} \mathrm{~g}^{-1}\right]}\end{array}$ & $\begin{array}{c}\text { Average } \\
\text { pore size } \\
\text { [nm] }\end{array}$ & $\begin{array}{c}\mathrm{VO}_{\mathrm{x}} \text { surface } \\
\text { density } \\
{\left[\mathrm{VO}_{x} \mathrm{~nm}^{-2}\right]}\end{array}$ & $\begin{array}{c}\text { Desorbed } \\
\mathrm{NH}_{3} \\
{\left[\mu \mathrm{molg}^{-1}\right]}\end{array}$ \\
\hline $\mathrm{ZrO}_{2}$ & - & 5 & 0.01 & 7.9 & - & 145 \\
\hline $\mathrm{VZr}$ & 3.2 & 4 & 0.01 & 7.8 & 53.0 & - \\
\hline $\mathrm{HfO}_{2}$ & - & 4 & 0.01 & 7.3 & - & 155 \\
\hline VHf & 3.1 & 4 & 0.01 & 7.3 & 51.3 & - \\
\hline$\gamma-\mathrm{Al}_{2} \mathrm{O}_{3}$ & - & 128 & 0.23 & 7.2 & - & 570 \\
\hline VAl & 3.2 & 124 & 0.22 & 7.1 & 1.7 & - \\
\hline
\end{tabular}


XRD patterns of the prepared catalysts and supports are shown in Figure 4. For the fresh $\gamma-\mathrm{Al}_{2} \mathrm{O}_{3}$ sample, the observed main diffraction peaks at $2 \theta$ of $37.3,45.5$, and $67^{\circ}$ indicate the presence of the cubic $\gamma-\mathrm{Al}_{2} \mathrm{O}_{3}$ phase (JCPDS 01-079-1557) [33,34]. Crystalline vanadium oxides were not detected on alumina-supported samples, which indicate that vanadium oxide is in a highly dispersed form on alumina or the crystallite size is less than $4 \mathrm{~nm}$ [35]. The main diffraction peaks for $\mathrm{ZrO}_{2}$ and $\mathrm{HfO}_{2}$ supported samples correspond to the monoclinic $\mathrm{ZrO}_{2}$ and $\mathrm{HfO}_{2}$ phases (JCPDS 03-065-1023, JCPDS 03-065-1142) $[36,37]$. The diffraction peaks of vanadia were observed at $2 \theta$ of $20.4,22.8,25.0,28.9$, and $34.0^{\circ}$ for fresh and used VZr and at 20.5, 22.9, 25.1, 29.1, and $34.2^{\circ}$ for fresh and used VHf (see supplementary material). These peaks indicate the presence of cubic mixed oxide phase $\mathrm{ZrV}_{2} \mathrm{O}_{7}$ on $\mathrm{ZrO}_{2}$ and $\mathrm{HfV}_{2} \mathrm{O}_{7}$ on $\mathrm{HfO}_{2}$ (JCPDS 01-088-0587, JCPDS 00-0300614). These results are in line with the results reported in the literature where high calcination temperature of highly loaded $\mathrm{VO} \times / \mathrm{ZrO}_{2}$ and $\mathrm{VO} / \mathrm{HfO}_{2}$, can cause formation of metal vanadate compounds $\mathrm{ZrV}_{2} \mathrm{O}_{7}$ or $\mathrm{HfV}_{2} \mathrm{O}_{7}$, respectively. [6,16] However, diffraction peaks at $2 \theta$ of $20.4,20.5,34.0$, and $34.2^{\circ}$ can indicate also presence of crystalline vanadium oxides (orthorhombic $\mathrm{VO}_{2}$, and orthorhombic $\mathrm{V}_{2} \mathrm{O}_{5}$ ) (JCPDS 04-005-4318, JCPDS 01-070-8747).

Figure 4. Diffraction peaks for a) $\mathrm{ZrO}_{2}$ based samples, b) $\mathrm{HfO}_{2}$ based samples, and c) $\gamma$ $\mathrm{Al}_{2} \mathrm{O}_{3}$ samples.

Crystallite sizes of $\mathrm{ZrO}_{2}$ and $\mathrm{HfO}_{2}$ based catalysts are reported in Table 4. With the $\mathrm{VZr}$ catalyst, the crystallite size of vanadia is slightly higher after the stability tests, in which case vanadia has sintered during the use. After the stability tests, the crystallite size of vanadia on the hafnia catalyst is decreased. When the crystallite sizes of supports are 
calculated, in the case of pure supports as well as after vanadia impregnation, the sizes are decreased after durability tests. It is important to observe here that crystallite sizes of vanadia have been determined from very small diffraction peaks. Furthermore, crystalline sulphur compounds were not observed in the used samples by XRD. Due to the small crystallinity and resolution of the data, the crystallite sizes of the alumina-based samples were not calculated.

Table 4. Crystallite sizes of $\mathrm{ZrO}_{2}, \mathrm{HfO}_{2}$ and vanadia.

\begin{tabular}{lcccc}
\hline & \multicolumn{2}{c}{ Crystallite sizes of support [nm] } & \multicolumn{2}{c}{ Crystallite sizes of vanadia [nm] } \\
Catalyst & Fresh & Used & Fresh & Used \\
\hline $\mathrm{ZrO}_{2}$ & 68 & 62 & - & - \\
$\mathrm{VZr}$ & 77 & 75 & 80 & 83 \\
$\mathrm{HfO}_{2}$ & 45 & 42 & - & - \\
$\mathrm{VHf}$ & 51 & 45 & 91 & 68 \\
\hline
\end{tabular}

The acidities of the samples were measured, because it has been earlier observed, that the acidity plays a role in the formation of formaldehyde and other products $[38,39]$. The total acidity of fresh samples was evaluated by $\mathrm{NH}_{3}$-TPD. The amounts of the desorbed $\mathrm{NH}_{3}$ for the fresh samples are shown in Table 3 presented earlier. According to Tatibouët [38], selective oxidation of methanol to formaldehyde requires both weak acid and basic sites. Weak acid sites of the material limit the $\mathrm{H}$ abstraction and weak basic sites prevent too strong adsorption of formaldehyde [38]. The $\gamma-\mathrm{Al}_{2} \mathrm{O}_{3}$ sample was more acidic than the other two supports. For all the samples, mostly weak and medium acid sites were observed (Figures not shown). 
In addition to quantity, the quality of the acid sites may also play a role in methanol oxidation. Wachs [7] studied distribution of surface Lewis and Brønsted acid sites on the alumina supported vanadium oxide catalysts. He observed that alumina support possesses Lewis acid sites, but after loading vanadium oxides on the supports, the number of surface Lewis acid sites is decreased and the number of surface Brønsted acid sites is increased [7]. Based on pyridine adsorption, we also observed the presence of Lewis acid sites on alumina. However, the $3 \mathrm{wt}-\%$ loading of vanadia did not increase Brønsted acidity. The adsorption of pyridine on $\mathrm{ZrO}_{2}$ was very low, and qualification of acid sites was not possible. On $\mathrm{HfO}_{2}$, very small amount of Lewis acid sites was observed and after $3 \%$ vanadia impregnation, also some Brønsted acid sites appeared. The VHf catalyst has a high surface density of surface vanadium species, which could demonstrate the Brønsted acid sites of the catalysts easier than VAI. Unfortunately we did not have possibility to realize lutidine adsorption that would reveal the Brønsted acidity better [40].

The microstructure and morphology of the particles of the fresh catalysts can be analysed with STEM. The EDS mapping was used to observe distribution of vanadium and support material elements. Vanadia particles were not observed with STEM (see supplementary material), but the EDS showed the existence of vanadium in the samples. Based on the EDS analysis, vanadium is better dispersed on the $\gamma-\mathrm{Al}_{2} \mathrm{O}_{3}$ support (Figure 5).

Furthermore, in addition to the well-dispersed part of vanadia, a few larger clusters were observed on $\mathrm{ZrO}_{2}$ and $\mathrm{HfO}_{2}$. This result is consistent with our results reported earlier in this paper.

Figure 5. Energy dispersive X-ray spectroscopy (EDS) mapping of vanadium distribution for the fresh catalysts (scale $200 \mathrm{~nm}$ ). 
Raman spectroscopy was used to compare the fresh and used catalytic materials further. Figures 6.a-c show Raman spectra of the fresh and used $\gamma-\mathrm{Al}_{2} \mathrm{O}_{3}$ and VAl catalysts. The spectrum of fresh $\gamma-\mathrm{Al}_{2} \mathrm{O}_{3}$ (Figure 6.a) shows clear bands at 1080, 415 and $299 \mathrm{~cm}^{-1}$. In addition, a group of bands is observed at $845,790,698$ and $600 \mathrm{~cm}^{-1}$. The measurements were done with time-gated Raman, which gives us richer spectral information compared with a conventional Raman device. The band at $1080 \mathrm{~cm}^{-1}$ is most probably originating from the $\mathrm{SO}_{4}{ }^{2-}$ impurity present in the commercial $\gamma-\mathrm{Al}_{2} \mathrm{O}_{3}$ (Merck). The less intense peaks between $600-845 \mathrm{~cm}^{-1}$ can be attributed to $\mathrm{Al}-\mathrm{OH}$ deformation and translation vibrations. The low-wavenumber bands of $415 \mathrm{~cm}^{-1}$ and $299 \mathrm{~cm}^{-1}$ could be related to Al-O-Al skeletal flexing vibrations. [41] The band at $415 \mathrm{~cm}^{-1}$ is also observed in the spectrum of $\alpha-\mathrm{Al}_{2} \mathrm{O}_{3}$ (sapphire). For the used $\gamma-\mathrm{Al}_{2} \mathrm{O}_{3}$ (Figure 6.a), a sharp new band appears at $975 \mathrm{~cm}^{-1}$ and a less intense band at $443 \mathrm{~cm}^{-1}$. These are related to the formation of aluminium sulphate.

When vanadium oxide is investigated by Raman, roughly three regions are observed: $V=O$ terminal stretching at $770-1050 \mathrm{~cm}^{-1}, \mathrm{~V}-\mathrm{O}-\mathrm{V}$ stretching at $500-800 \mathrm{~cm}^{-1}$ and $\mathrm{V}-\mathrm{O}-\mathrm{V}$ bending at $150-400 \mathrm{~cm}^{-1}$. [30] The Raman spectrum of fresh VAl shows a strong band at $935 \mathrm{~cm}^{-1}$, which corresponds to the terminal stretching mode of the $\mathrm{V}=\mathrm{O}$ bond in a polymeric tetrahedral $\mathrm{VO}_{4}$ chain. This is typically observed for the vanadia loadings of less than $5 \%$ supported on $\mathrm{Al}_{2} \mathrm{O}_{3}$. In the measured spectra, peaks at the metavanadate $\mathrm{V}-\mathrm{O}-\mathrm{V}$ bending and stretching regions are also present. [30] For the used VAl, the spectrum is different: the $935 \mathrm{~cm}^{-1}$ band disappears, and new bands are observed at 1099, 1010, 902, $782,634,467$ and $280 \mathrm{~cm}^{-1}$. Unfortunately, the vanadia vibrations and those caused by sulphur compounds appear very close to each other, which complicates the interpretation of the spectra. The band at $1010 \mathrm{~cm}^{-1}$ could be resolved as terminal $\mathrm{V}=\mathrm{O}$ vibration of surface vanadyl $\left(\mathrm{VO}^{2+}\right)$ species (when taking into account the spectral resolution of the 
device). However, $\mathrm{VOSO}_{4}$, and aluminium sulphate have an intense peak at the same region. Since we did not observe peaks at around 1025 and $1075 \mathrm{~cm}^{-1}$ belonging to $\mathrm{VOSO}_{4}$, we could not confirm the presence of $\mathrm{VOSO}_{4}$ in the sample. For the used $\mathrm{VAI}$ sample at higher wavenumber region, we observed peaks at around 1060, 1150 and 1420 $\mathrm{cm}^{-1}$, which were not visible for the fresh sample. Dunn et al. [42] have studied surface sulphate species on metal oxide catalysts. For the dehydrated $5 \% \mathrm{~V}_{2} \mathrm{O}_{5} / \mathrm{Al}_{2} \mathrm{O}_{3}$, they observed a peak to appear at $1382 \mathrm{~cm}^{-1}$, which was related to the terminal $\mathrm{S}=\mathrm{O}$ of tridentate surface sulphates coordinated on an alumina support. Due to the broadness of the peak observed in our case at around $1420 \mathrm{~cm}^{-1}$, this peak could be related to the sulphates on alumina.

We expect also that a change in vanadium oxidation state occurred during the long-term experiment, since the colour of the catalyst changed from yellow to somewhat greenish. We did not observe the presence of crystalline $\mathrm{V}_{2} \mathrm{O}_{5}$ nanoparticles on $\gamma-\mathrm{Al}_{2} \mathrm{O}_{3}$, but they are usually observed in connection with the high loading of vanadia [30].

As a conclusion from this analysis, we may say that certain sulphate species are observed mainly on the $\gamma-\mathrm{Al}_{2} \mathrm{O}_{3}$ support in addition to a probable change in vanadium oxidation state. In the fresh sample, mainly $\mathrm{V}^{5+}$ (vanadate, $\mathrm{VO}_{4}{ }^{3-}$ ) is present, while in the used sample also $\mathrm{V}^{4+}$ (vanadyl, $\mathrm{VO}^{2+}$ ) appears. For more exact resolving of the spectra, further studies are needed.

Figure 6. Timegated Raman spectra of a) fresh and used $\gamma-\mathrm{Al}_{2} \mathrm{O}_{3}, \mathrm{~b}-\mathrm{c}$ ) fresh and used VAl.

The Raman spectra of fresh zirconia and fresh and used VZr are presented in Figure 7a-b. Figure 7.a represents a typical spectrum of monoclinic $\mathrm{ZrO}_{2}$, which is the stable phase of $\mathrm{ZrO}_{2}$ at room temperature [43]. After impregnation of $3 \%$ vanadia on $\mathrm{ZrO}_{2}$, a new Raman 
band appears at $995 \mathrm{~cm}^{-1}$. Previously, for $5 \% \mathrm{~V}_{2} \mathrm{O}_{5} / \mathrm{ZrO}_{2}$, the Raman bands have been observed at 1030 and $920 \mathrm{~cm}^{-1}$. According to Bañares and Wachs [44] and Khodakov et al. [10], a higher wavenumber band is related to a terminal $\mathrm{V}=\mathrm{O}$ bond stretching in isolated monovanadate species [44] while bands observed in the $800-600 \mathrm{~cm}^{-1}$ region are stretching modes in polyvanadate species [10]. As Deo [30] has earlier remarked, higher polymerization of $\mathrm{VO}_{4}$ monomers shifts this band to lower wavenumbers. In our case, it seems likely, that vanadia on $\mathrm{ZrO}_{2}$ is in a less polymerized form than when supported on $\gamma$ $\mathrm{Al}_{2} \mathrm{O}_{3}$. After vanadia impregnation on $\mathrm{ZrO}_{2}$, a new band is also observed at $774 \mathrm{~cm}^{-1}$. This can be related to the V-O-V stretching vibration, which has been observed between 875 $600 \mathrm{~cm}^{-1}$ for dehydrated $4 \% \mathrm{~V}_{2} \mathrm{O}_{5} / \mathrm{Al}_{2} \mathrm{O}_{3}$ and between $485-865 \mathrm{~cm}^{-1}$ for a catalyst in the presence of moisture at $230^{\circ} \mathrm{C}$ [44]. It may also be related to presence of $\mathrm{ZrV}_{2} \mathrm{O}_{7}$, since it exhibits two strong Raman peaks at about 985 and $770 \mathrm{~cm}^{-1}$. [21]

In 2013, Wachs [14] reviewed the aspects related to vanadium oxide supported on different metal oxides. He observed that after the monolayer coverage, vanadia starts to form in addition to surface oxide species, the crystalline $\mathrm{V}_{2} \mathrm{O}_{5}$ particles. The presence of these particles could be observed by Raman measurements and over a $\mathrm{V}_{2} \mathrm{O}_{5} / \mathrm{ZrO}_{2}$ catalyst with a band located at around $995 \mathrm{~cm}^{-1}$. It may be possible in our case, that also crystalline $\mathrm{V}_{2} \mathrm{O}_{5}$ particles are present on the catalyst, since the band observed in the $\mathrm{VZr}$ spectrum falls exactly at $995 \mathrm{~cm}^{-1}$. The complete absence of higher wavenumber bands indicating the surface oxide species, however, adds some doubt to this conclusion made only by Raman analysis. When we take into consideration the XRD results, we are able to make the conclusion related to the presence of crystalline particles, since orthorhombic $\mathrm{V}_{2} \mathrm{O}_{5}$ was observed on the surface of VZr. This conclusion is also supported by the low specific 
surface area of $\mathrm{ZrO}_{2}$, which may lead to the monolayer coverage with a smaller vanadium loading.

In general, the observed Raman signals may move to the lower wavenumbers due to the presence of residual moisture and amorphous nature of the material [43]. In contrast, the high loading of vanadia shifts the position of the band at higher wavenumbers [19]. The band observed at $384 \mathrm{~cm}^{-1}$ in pure $\mathrm{ZrO}_{2}$ shifts to $375 \mathrm{~cm}^{-1}$ after impregnation of vanadia. This may originate from the bending mode of $\mathrm{V}-\mathrm{O}$ or $\mathrm{V}-\mathrm{O}-\mathrm{V}$ species and their interaction with the zirconia support. [44] Finally, we can conclude that the fresh VZr catalyst contains $\mathrm{V}_{2} \mathrm{O}_{5}$ crystals and polyvanadate species with vanadium oxidation state of +5 , however, in a less polymerized form than when supported on $\gamma-\mathrm{Al}_{2} \mathrm{O}_{3}$. Furthermore, in addition to these, Raman and XRD analyses show the possibility of the presence of $\mathrm{ZrV}_{2} \mathrm{O}_{7}$ species.

Figure 7. Timegated Raman spectra of a) fresh $\mathrm{ZrO}_{2}$ and $\mathrm{VZr}$, b) fresh and used $\mathrm{VZr}$.

When the Raman spectra of fresh and used zirconia materials were compared, no significant differences were observed indicating a better stability of these materials compared with those based on alumina (see the supplementary material). At a higher wavenumber region, the appearance of a peak in the region of around $1400 \mathrm{~cm}^{-1}$ is observed. Based on the findings of Dunn et al. [42], it indicates the interaction of the material with sulphur. Furthermore, a small shoulder appearing in the spectrum of the used $\mathrm{ZrO}_{2}$ support at around $1295 \mathrm{~cm}^{-1}$ may indicate the presence of tridentate terminal $\mathrm{S}=\mathrm{O}$ on zirconia. As a conclusion, the zirconia support, and especially after the impregnation of vanadia, seems to be more stable towards sulphur-induced deactivation than the corresponding alumina-supported catalyst. 
The Raman spectra of hafnia-containing catalysts are presented in Figure 8.a-c. The spectrum of fresh hafnia represents a typical spectrum observed for monoclinic hafnia [45,46]. After vanadia impregnation, a new band appears at $992 \mathrm{~cm}^{-1}$, which is the same than that observed for zirconia. Based on the earlier discussions, as in the case of $\mathrm{ZrO}_{2}$, this band may indicate the presence of $\mathrm{V}_{2} \mathrm{O}_{5}$ crystals. A new band is observed also at 795 $\mathrm{cm}^{-1}$, which could be related to the $\mathrm{V}-\mathrm{O}-\mathrm{V}$ stretching vibration of polyvanadate species or the presence of $\mathrm{HfV}_{2} \mathrm{O}_{7}$. Thus, on $\mathrm{HfO}_{2}$ the presence of polyvanadate species, $\mathrm{HfV}_{2} \mathrm{O}_{7}$ and crystalline $\mathrm{V}_{2} \mathrm{O}_{5}$ seems likely. Furthermore, the presence of crystalline $\mathrm{HfV}_{2} \mathrm{O}_{7}$ and orthorhombic $\mathrm{V}_{2} \mathrm{O}_{5}$ on $\mathrm{HfO}_{2}$ was confirmed by XRD. Similarly to the case of zirconia, after comparison of the Raman spectra of fresh and used materials, we observe an indication of better stability of the materials in the reaction conditions than that for alumina-containing materials. Furthermore, even though the appearance of the band at around $1220 \mathrm{~cm}^{-1}$ was observed for the used $\mathrm{HfO}_{2}$ support, no such changes were observed after the vanadia impregnation.

Figure 8. Timegated Raman spectra of a) fresh $\mathrm{HfO}_{2}$ and $\mathrm{VHf}$, b) fresh and used $\mathrm{HfO}_{2}$, and c) fresh and used VHf.

When looking the XRD, Raman and activity results, we observe that the better activity of VAl catalyst could be explained by the presence of a higher amount of surface $\mathrm{VO}_{\mathrm{x}}$ species. This is supported by the findings of Wachs [14]. In $\mathrm{HfO}_{2}$ and $\mathrm{ZrO}_{2}$ supported catalysts, the presence of $\mathrm{ZrV}_{2} \mathrm{O}_{7}, \mathrm{HfV}_{2} \mathrm{O}_{7}$, and $\mathrm{V}_{2} \mathrm{O}_{5}$ crystals was observed, while on $\gamma$ $\mathrm{Al}_{2} \mathrm{O}_{3} \mathrm{~V}_{2} \mathrm{O}_{5}$ was not observed.

To obtain more information on the possible presence of vanadium (IV) on the catalysts, an EPR study was done. Figure 9 shows the EPR results of $\gamma-\mathrm{Al}_{2} \mathrm{O}_{3}$ supported catalysts. 
Concerning the VAl catalysts, the EPR spectra recorded at room temperature display a signal, which indicates the presence of $\mathrm{VO}^{2+}$ sites. Indeed, the $\mathrm{VO}^{2+}$ ion has a d1 electronic configuration, which means that under a magnetic field, the electron orientation can be parallel or antiparallel ( $m s=+1 / 2$ or $-1 / 2$ ). The nuclear spin of $V^{4+}$ is $I=7 / 2$, and a hyperfine interaction between $S$ and I can occur. This leads to a split of the two electronic states into $2 \mathrm{I}+1$ sublevels. Thus, (Figure 9b) a complicated hyperfine structure is revealed for the spectra of the VAl samples recorded at $77 \mathrm{~K}$ corresponding to an anisotropic system. For an axial symmetry, the $g$ components are $g_{z z}=g_{/ /}$and $g_{x x}=g_{z z}=g_{\perp}$, and the hyperfine tensors are $A / /$ and $A_{\perp}$. These well resolved lines are split by the interaction with the vanadium nucleus into eight superimposed hyperfine structure lines. This hyperfine signal with the following parameters: $\mathrm{g} / /=1.941, \mathrm{~g}_{\perp}=1.968, \mathrm{~A}_{/ /}=189.2 \mathrm{G}$ and $\mathrm{A}_{\perp}=62.8 \mathrm{G}$ can be attributed to the isolated $\mathrm{VO}^{2+}$ species. It could be mentioned that this hyperfine signal is well resolved and stronger for the used sample indicating higher concentration of isolated species in the used catalyst. The increased amount of $\mathrm{V}^{4+}$ in the used catalyst is supported by the Raman analysis and by the visually observed colour change (from yellow to blue/green) after the stability test. The amount of $\mathrm{V}^{4+}$ can be very low in the aluminasupported catalyst, because EPR analysis is a very sensitive technique and it can detect traces of $\mathrm{V}^{4+}$. However, these traces of minor species or vacancies can have notable positive or negative effect on the activity of a catalyst.

Figure 9. EPR results of a) alumina and alumina-based catalysts, and b) the fresh VAl and used VAI.

The formation of $V^{4+}$ was not observed with zirconia and hafnia supported catalysts. After the stability test, it was noticed that the VAl catalyst was the most unstable and the changes were noticed particularly in the formaldehyde production and conversion of 
methanol. Therefore, the amount of $\mathrm{V}^{5+}$ may have an important role in the methanol oxidation to formaldehyde. After stability tests, changes were not observed in the MT conversion and $\mathrm{SO}_{2}$ formation. This may indicate that methanethiol and methanol react on different active sites, or this reaction proceeds also in a non-catalytic way.

The X-ray photoelectron spectroscopy (XPS) was used for the determination of vanadium and sulphur contents on the studied samples and the oxidation states of materials. The surface vanadium and sulphur contents (wt-\%) of the samples are presented in Table 5. With the VZr and VHf catalysts, the surface vanadium concentration was higher than the total vanadium concentration of the samples (see Table 3). This was expected due to the high $\mathrm{VO}_{\mathrm{x}}$ surface density of the samples. With all the catalysts, the content of surface vanadium decreased by $0.5-1.3 \%$-points during the 16 hours stability test. After the stability tests, the amount of sulphur on the surface of supports was $1.4-1.9 \mathrm{wt}-\%$. The vanadium impregnation decreased the sulphur content on the used VZr and VHf catalysts and increased the sulphur content on the used VAl catalyst. In the stability tests, the VHf catalyst was observed to be the most stable among the tested materials. This is in accordance with the results of XPS analysis. It should be still remembered that XPS analysis is a very surface sensitive technique. For that reason, it cannot observe sulphur species that are located deeper in the porous structure [47]. These results suggest that the catalysts ( $\mathrm{VZr}$ and $\mathrm{VHf}$ ) with a high $\mathrm{VO}_{\mathrm{x}}$ surface density were more stable against sulphur than catalysts (VAl) with a low $\mathrm{VO}_{x}$ surface density. In other words, formation of $\mathrm{ZrV}_{2} \mathrm{O}_{7}$, $\mathrm{HfV}_{2} \mathrm{O}_{7}$, and $\mathrm{V}_{2} \mathrm{O}_{5}$ crystallites on the support surface may increase the stability of material and decrease the deposition of sulphur. In 2009 and 2015, Soriano et al. [11,12] studied the vanadium catalysts stabilities in the partial oxidation of hydrogen sulphide. They observed also that the deposition of sulphur is favoured on catalysts presenting dispersed 
vanadia species and the formation of $\mathrm{V}_{2} \mathrm{O}_{5}$ crystallites increases the stability of vanadium catalysts $[11,12]$.

Table 5. Surface content of vanadium and sulphur for the samples.

\begin{tabular}{lcc}
\hline Sample & $\mathrm{V}[\mathrm{wt}-\%]$ & $\mathrm{S}[\mathrm{wt}-\%]$ \\
\hline Used $\mathrm{ZrO}_{2}$ & - & 1.9 \\
Used $\mathrm{HfO}_{2}$ & - & 1.4 \\
Used $\gamma-\mathrm{Al}_{2} \mathrm{O}_{3}$ & - & 1.5 \\
Fresh VZr & 6.9 & - \\
Used $\mathrm{VZr}$ & 5.6 & 0.3 \\
Fresh VHf & 5.2 & - \\
Used VHf & 4.2 & 0.1 \\
Fresh VAl & 2.0 & - \\
Used VAl & 1.5 & 2.9 \\
\hline
\end{tabular}

The use of XPS in the determination of vanadium oxidation states is very challenging. According to Rhimi et al. [48] and Suchorski [49], the ultra-high vacuum (UHV) conditions and the interaction of the X-rays during the XPS measurements can cause reduction of V oxide species or a decrease in the $\mathrm{V}^{5+} / \mathrm{V}^{4+}$ ratio. For that reason, the results of the oxidation states of vanadium are not presented.

The XPS spectra of $S 2 p$ for the used supports and catalysts is shown in Figure 10. According to the literature, the typical S $2 p$ binding energy values for the sulphate are between 168.2-171.0 eV [47,50-52]. For all the used samples, the deconvolution of the $S$ $2 p$ spectra revealed two peaks that correspond to $S 2 p_{1 / 2}$ and $S 2 p_{3 / 2}$ signals of sulphates. The results show that sulphur is present in the oxidation state of $6+$ in sulphates. 
Figure 10. The XPS spectra of $S 2 p$ for the samples after stability tests.

The XPS spectra of O 1s consisted of two main peaks in the fresh and used samples. The low energy peak is located at $529.5-530.5 \mathrm{eV}$, which corresponds to the lattice oxygen $\left(\mathrm{O}_{\alpha}\right)$ of vanadium, aluminium, zirconium, and/or hafnium oxides. The higher binding energy peak is observed at $530.8-531.8 \mathrm{eV}$, which can be attributed to the chemisorbed oxygen $\left(\mathrm{O}_{\beta}\right)$ of surface hydroxyl groups $(-\mathrm{OH}) .[52-55]$ Based on the literature, the binding energies of $\mathrm{O} 1 \mathrm{~s}$ for sulphate are in the range of $531.5-533 \mathrm{eV}[51,54-56]$. In our study, oxygen of sulphate is located at $531.6-532.3 \mathrm{eV}$ in the used samples. (see supplementary material)

The binding energy values of $\mathrm{Zr} 3 d, A l p_{3 / 2}, \mathrm{Hf} 4 \mathrm{f}, \mathrm{V} 2 p_{3 / 2}, \mathrm{~S} 2 \mathrm{p}$, and O1s for all fresh and used samples are presented in the supplementary material. For all the $\mathrm{Zr}$-containing samples, the deconvolution of the $\mathrm{Zr} 3 \mathrm{~d}$ spectra revealed two peaks with binding energy values of $181.6-182.6 \mathrm{eV}$ and $184.0-185.0 \mathrm{eV}$ that correspond to $\mathrm{Zr} 3 \mathrm{~d}_{5 / 2}$ and $\mathrm{Zr} 3 \mathrm{~d}_{3 / 2}$ signals, respectively. The binding energy values of $Z r 3 d_{5 / 2}$ can be attributed to the oxidation state of $\mathrm{Zr}^{4+}$ in $\mathrm{ZrO}_{2}[51,52,57,58]$. For all the Hf-containing samples, the deconvolution of the $\mathrm{Hf} 4 \mathrm{f}$ spectra revealed two peaks with binding energy values of 16.3$17.2 \mathrm{eV}$ and $17.9-18.8 \mathrm{eV}$ that correspond to $\mathrm{Hf}_{4} \mathrm{f}_{7 / 2}$ and $\mathrm{Hf} 4 \mathrm{f}_{5 / 2}$ signals, respectively. Based on the literature, the measured binding energy values of $\mathrm{Hf} 4 \mathrm{f}_{7 / 2}$ can be attributed to the oxidation states of $4^{+}$in $\mathrm{HfO}_{2}[51,53,59]$. For all the Al-containing samples, the deconvolution of the Al $2 p$ spectra revealed one peak between $73.8-74.2 \mathrm{eV}$, which is related to the Al 2p $2 / 3$ signal. Based on Moulder et al. [51] and Chary et al. [60], these values correspond to the oxidation state of +3 in $\mathrm{Al}_{2} \mathrm{O}_{3}$. The addition of vanadia on supports or the use of the samples in the stability tests did not change the oxidation state observed for the support metal. 


\section{Conclusions}

In this study, activity, selectivity and stability of vanadium catalysts supported on zirconia, hafnia, and alumina were examined in the partial oxidation of methanethiol and methanol mixture to formaldehyde. The properties and sulphur deactivation of the samples were evaluated by using several characterisation methods.

The results showed that impregnation of vanadium on the support increased the amount of formaldehyde production and decreased the formaldehyde formation temperature. The largest improvement in efficiency was observed with the $3 \mathrm{wt}-\% \mathrm{~V}_{2} \mathrm{O}_{5} / \gamma-\mathrm{Al}_{2} \mathrm{O}_{3}$ catalyst. With all the samples, DMDS and CO were formed as the by-products. The oxidation results suggested that most of DMDS was formed thermally, since it was easily formed also without a catalyst. Formation of DMS was observed with $\gamma-\mathrm{Al}_{2} \mathrm{O}_{3}$, which indicates the simultaneous formation of $\mathrm{H}_{2} \mathrm{~S}$. However, after vanadium impregnation the formation of DMS practically disappeared. The results showed an important relation of the quality of surface $\mathrm{VO}_{x}$ species with activity and selectivity of the catalysts.

After the stability tests, no decline in activity of supports was observed. However, after impregnation of vanadium, differences in the formaldehyde and $\mathrm{SO}_{2}$ production as well as methanol conversion were noticed. Of the catalysts, the $3 \mathrm{wt}-\% \mathrm{~V}_{2} \mathrm{O}_{5} / \mathrm{HfO}_{2}$ was the most stable and according to XPS contained lowest amount of surface sulphur. Even though the 3 wt- $\% \mathrm{~V}_{2} \mathrm{O}_{5} / \gamma-\mathrm{Al}_{2} \mathrm{O}_{3}$ catalyst was the most active, it was deactivated by sulphur. The deactivation seems to be a consequence from the formation of sulphates on alumina, removal of vanadium surface species and changes in the oxidation state of vanadium. These results suggest that the formation of a metal-mixed oxide phases between 
vanadium and the support $\left(\mathrm{HfO}_{2}\right.$ and $\left.\mathrm{ZrO}_{2}\right)$ increases the catalytic stability and decreases the deposition of sulphur.

\section{Acknowledgements}

The financial support of Jenny and Antti Wihuri foundation, Finnish Cultural Foundation North Ostrobothnia regional fund, Walter Ahlström foundation, Riitta and Jorma J.

Takanen foundation and Academy of Finland through Electra project is acknowledged. Kaisu Ainassaari, Markus Riihimäki and Jorma Penttinen are acknowledged for their assistance in the characterisation of materials. Lucette Tidahy is acknowledged for the EPR measurements. The Center of Microscopy and Nanotechnology (CMNT) at the University of Oulu is acknowledged for the guidance in the STEM, EDS, and XPS analyses.

\section{Appendix A. Supplementary material}

\section{References}

[1] S. Ojala, N. Koivikko, T. Laitinen, A. Mouammine, P. Seelam, S. Laassiri, K. Ainassaari, R. Brahmi, R. Keiski, Catalysts 2015, 5(3), 1092-1151, https://doi.org/10.3390/catal5031092.

[2] M. Badshah, W. Parawira, B. Mattiasson, Bioresour. Technol. 2012, 125, 318-327, https://doi.org/10.1016/j.biortech.2012.08.109.

[3] P. Bajpai, Pulp and Paper Industry: Energy Conservation. Elsevier, 2016, pp. 103123. https://doi.org/10.1016/B978-0-12-803411-8.00007-X.

[4] T.L. Burgess, A.G. Gibson, S.J. Furstein, I.E. Wachs, Environ. Prog. 2002, 21(3), 137-141, https://doi.org/10.1002/ep.670210311. 
[5] N. Koivikko, T. Laitinen, S. Ojala, S. Pitkäaho, A. Kucherov, R.L. Keiski, Appl. Catal. B. Environ. 2011, 103(1-2), 72-78, https://doi.org/10.1016/j.apcatb.2011.01.010.

[6] B. Olthof, A. Khodakov, A.T. Bell, E. Iglesia, J. Phys. Chem. B. 2000, 104(7), 15161528, https://doi.org/10.1021/jp9921248.

[7] I.E. Wachs, Catal. Today. 1996, 27(3-4), 437-455, https://doi.org/10.1016/09205861(95)00203-0.

[8] I.E. Wachs, B.M. Weckhuysen, Appl. Catal. A. Gen. 1997, 157(1-2), 67-90, https://doi.org/10.1016/S0926-860X(97)00021-5.

[9] G.C. Bond, S.F. Tahir, Appl. Catal. 1991, 71(1), 1-31, https://doi.org/10.1016/01669834(91)85002-D.

[10] A. Khodakov, B. Olthof, T. Bell, E. Iglesia, J. Catal. 1999, 181(2), 205-216, https://doi.org/10.1006/jcat.1998.2295.

[11] M.D. Soriano, J.A. Cecilia, A. Natoli, J. Jiménez-Jiménez, J.M. López Nieto, E. Rodríguez-Castellón, Catal. Today. 2015, 254, 36-42, https://doi.org/10.1016/j.cattod.2014.12.022.

[12] M.D. Soriano, J. Jiménez-Jiménez, P. Concepción, A. Jiménez-López, E. Rodríguez-Castellón, J.M.L. Nieto, Appl. Catal. B. Environ. 2009, 92(3-4), 271-279, https://doi.org/10.1016/j.apcatb.2009.08.002.

[13] S. Xie, E. Iglesia, A.T. Bell, Langmuir. 2000, 16(18), 7162-7167, https://doi.org/10.1021/la0003342.

[14] I.E. Wachs, Dalt. Trans. 2013, 42(33), 11762-11769, 
https://doi.org/10.1039/c3dt50692d.

[15] J. Wang, G. Li, Z. Li, C. Tang, Z. Feng, H. An, H. Liu, T. Liu, C. Li, Sci. Adv. 2017, 3(10), 1-11, https://doi.org/10.1126/sciadv.1701290.

[16] A. Christodoulakis, M. Machli, A. lemonidou, S. Boghosian, J. Catal. 2004, 222(2), 293-306, https://doi.org/10.1016/j.jcat.2003.10.007.

[17] N. Koivikko, T. Laitinen, A. Mouammine, S. Ojala, R. Keiski, Catalysts. 2018, 8(2), 56, https://doi.org/10.3390/catal8020056.

[18] Y. Zhao, Z. Qin, G. Wang, M. Dong, L. Huang, Z. Wu, W. Fan, J. Wang, Fuel. 2013, 104, 22-27, https://doi.org/10.1016/j.fuel.2010.03.008.

[19] T. Kim, I.E. Wachs, J. Catal. 2008, 255(2), 197-205, https://doi.org/10.1016/j.jcat.2008.02.007.

[20] R.H. Nielsen, G. Wilfing, Hafnium and Hafnium Compounds. In: Ullmann's Encyclopedia of Industrial Chemistry. Wiley-VCH, Weinheim, 2010 pp. 191-202. https://doi.org/10.1002/14356007.a12_559.pub2.

[21] J.L. Male, H.G. Niessen, A.T. Bell, T. Don Tilley, J. Catal. 2000, 194(2), 431-444, https://doi.org/10.1006/jcat.2000.2938.

[22] C.A. Emeis, J. Catal. 1993, 141(2), 347-354, https://doi.org/10.1006/jcat.1993.1145.

[23] J. Kostamovaara, J. Tenhunen, M. Kögler, I. Nissinen, J. Nissinen, P. Keränen, Opt Express. 2013, 21(25), 31632, https://doi.org/10.1364/OE.21.031632.

[24] S. Bashkova, A. Bagreev, T.J. Bandosz, Ind. Eng. Chem. Res. 2002, 41(17), 43464352, https://doi.org/10.1021/ie020137t. 
[25] A.K. Dalai, E.L. Tollefson, A. Yang, E. Sasaoka, Ind. Eng. Chem. Res. 1997, 36(11), 4726-4733, https://doi.org/10.1021/ie9701231.

[26] D. He, D. Chen, H. Hao, J. Yu, J. Liu, J. Lu, G. Wan, S. He, K. Li, Y. Luo, Chem. Eng. J. 2017, 317, 60-69, https://doi.org/10.1016/j.cej.2017.02.067.

[27] E. Huguet, B. Coq, R. Durand, C. Leroi, R. Cadours, V. Hulea, Appl. Catal. B. Environ. 2013, 134-135, 344-348, https://doi.org/10.1016/j.apcatb.2013.01.037.

[28] V. Hulea, E. Huguet, C. Cammarano, A. Lacarriere, R. Durand, C. Leroi, R. Cadours, B. Coq, Appl. Catal. B. Environ. 2014, 144, 547-553, https://doi.org/10.1016/j.apcatb.2013.07.056.

[29] G. Reuss, W. Disteldorf, A.O. Gamer, A. Hilt, Formaldehyde. In: Ullmann's Encyclopedia of Industrial Chemistry. Wiley-VCH, Weinheim. 2012, 15, 735-768, https://doi.org/10.1002/14356007.a11.

[30] G. Deo, F.D. Hardcastle, M. Richards, A.M. Hirt, I.E. Wachs, Chapter 29 - Raman Spectroscopy of Vanadium Oxide Supported on Alumina. In: Novel Materials in Heterogeneous Catalysis. ACS Symposium Series, Volume 437. ACS, Washington, 1990, pp. 317-328. https://doi.org/10.1021/bk-1990-0437.ch029.

[31] R.H. Nielsen, G. Wilfing, Zirconium and Zirconium Compounds. In: Ullmann's Encyclopedia of Industrial Chemistry. Wiley-VCH, Weinheim, 2010, pp. 753-778. https://doi.org/10.1002/14356007.a28_543.pub2.

[32] G. Deo, I.E. Wachs, Crit. Rev. Surf. Chem. 1994, 4(3/4), 141-187, https://doi.org/10.1002/chin.199603284.

[33] N. Firdous, N.K. Janjua, I. Qazi, M.H. Sarwar Wattoo, Int. J. Hydrogen Energy. 2016, 
41(2), 984-995, https://doi.org/10.1016/j.ijhydene.2015.10.084.

[34] Y. Meng, T. Wang, S. Chen, Y. Zhao, X. Ma, J. Gong, Appl. Catal. B. Environ. 2014, 160-161(1), 161-172, https://doi.org/10.1016/j.apcatb.2014.05.008.

[35] B.M. Reddy, B. Manohar, E.P. Reddy, Langmuir. 1993, 9(7), 1781-1785, https://doi.org/10.1021/la00031a028.

[36] S. Colussi, M. Boaro, L. de Rogatis, A. Pappacena, C. de Leitenburg, J. Llorca, A. Trovarelli, Catal. Today. 2015, 253, 163-171, https://doi.org/10.1016/j.cattod.2015.02.028.

[37] M.K. Gnanamani, L.Z. Linganiso, G. Jacobs, R.A. Keogh, W.D. Shafer, B.H. Davis, Catal. Letters. 2012, 142(10), 1180-1189, https://doi.org/10.1007/s10562-012-08825.

[38] J.M. Tatibouet, Appl. Catal. A. Gen. 1997, 148, 213-252 https://doi.org/10.1016/S0926-860X(96)00236-0.

[39] M. Trejda, M. Ziolek, Y. Millot, K. Chalupka, M. Che, S. Dzwigaj, J. Catal. 2011, 281(1), 169-176, https://doi.org/10.1016/j.jcat.2011.04.013.

[40] Z. El Assal, S. Ojala, S. Pitkäaho, L. Pirault-Roy, B. Darif, J.D. Comparot, M. Bensitel, R.L. Keiski, R. Brahmi, Chem. Eng. J. 2017, 313, 1010-1022, https://doi.org/10.1016/j.cej.2016.10.139.

[41] H.D. Ruan, R.L. Frost, J.T. Kloprogge, J Raman Spectrosc. 2001, 32(9), 745-750, https://doi.org/10.1002/jrs.736.

[42] J.P. Dunn, J.M. Jehng, D.S. Kim, L.E. Briand, H.G. Stenger, I.E. Wachs, J. Phys. 
Chem. B. 1998, 102(32), 6212-6218, https://doi.org/10.1021/jp9814247.

[43] F. Adar, Spectroscopy. 2014, 29(10), 14-22,.

[44] M.A. Bañares, I.E. Wachs, J. Raman Spectrosc. 2002, 33(5), 359-380, https://doi.org/10.1002/jrs.866.

[45] H. Padma Kumar, S. Vidya, S. Saravana Kumar, C. Vijayakumar, S. Solomon, J.K. Thomas, J. Asian Ceram. Soc. 2015, 3(1), 64-69, https://doi.org/10.1016/j.jascer.2014.10.009.

[46] J.S. Quintero-García, B.A. Puente-Urbina, L.A. García-Cerda, O.S. RodríguezFernández, E. Mendoza-Mendoza, Mater. Lett. 2015, 159, 520-524, https://doi.org/10.1016/j.matlet.2015.07.014.

[47] R.P.W.J. Struis, T.J. Schildhauer, I. Czekaj, M. Janousch, S.M.A. Biollaz, C. Ludwig, Appl. Catal. A. Gen. 2009, 362(1-2), 121-128, https://doi.org/10.1016/j.apcata.2009.04.030.

[48] B. Rhimi, M. Mhamdi, A. Ghorbel, V.N. Kalevaru, A. Martin, M. Perez-Cadenas, A. Guerrero-Ruiz, J. Mol. Catal. A. Chem. 2016, 416, 127-139, https://doi.org/10.1016/j.molcata.2016.02.028.

[49] Y. Suchorski, L. Rihko-Struckmann, F. Klose, Y. Ye, M. Alandjiyska, K. Sundmacher, H. Weiss, Appl. Surf. Sci. 2005, 249(1-4), 231-237, https://doi.org/10.1016/j.apsusc.2004.11.083.

[50] L. V. Duong, B.J. Wood, J.T. Kloprogge, Mater. Lett. 2005, 59(14-15), 1932-1936, https://doi.org/10.1016/j.matlet.2005.02.029. 
[51] J.F. Moulder, W.F. Stickle, P.E. Sobol, K.D. Bomben in: Handbook of X-Ray Photoelectron Spectroscopy. (Eds.: J. Chastain). Perkin-Elmer Corporation, Minnesota, 1992.

[52] A. Väliheikki, T. Kolli, M. Huuhtanen, T. Maunula, R.L. Keiski, Top. Catal. 2015, 58(14-17), 1002-1011, https://doi.org/10.1007/s11244-015-0469-7.

[53] B.M. Reddy, G. Thrimurthulu, L. Katta, Catal. Letters. 2011, 141(4), 572-581, https://doi.org/10.1007/s10562-010-0484-z.

[54] H. Zhao, S. Bennici, J. Shen, A. Auroux, Appl. Catal. A. Gen. 2009, 356(2), 121-128, https://doi.org/10.1016/j.apcata.2008.12.037.

[55] H. Zhao, S. Bennici, J. Cai, J. Shen, A. Auroux, Catal. Today. 2010, 152(1-4), 70-77, https://doi.org/10.1016/j.cattod.2009.08.005.

[56] J. Wen, H.O.U. Ya-qin, G.U.O. Qian-qian, H. Zhang-gen, H.A.N. Xiao-jin, J. Fuel Chem. Technol. 2013, 41(10), 1223-1233, https://doi.org/10.1016/S18725813(13)60050-X.

[57] S. Gao, X. Chen, H. Wang, J. Mo, Z. Wu, Y. Liu, X. Weng, J. Colloid Interface Sci. 2013, 394, 515-521, https://doi.org/10.1016/j.jcis.2012.12.034.

[58] T.L. Barr, J. Phys. Chem. 1978, 82(16), 1801-1810, https://doi.org/10.1021/j100505a006.

[59] M.F. Al-Kuhaili, S.M.A. Durrani, I.A. Bakhtiari, M.A. Dastageer, M.B. Mekki, Mater. Chem. Phys. 2011, 126(3), 515-523, https://doi.org/10.1016/j.matchemphys.2011.01.036. 
[60] K.V.R. Chary, C.P. Kumar, D. Naresh, T. Bhaskar, Y. Sakata, J. Mol. Catal. A. Chem. 2006, 243(2), 149-157, https://doi.org/10.1016/j.molcata.2005.07.036. 